\title{
1-Pyrenyl- and 3-perylenyl-antimony(V) derivatives for the fluorescence turn-on sensing of fluoride ions in water at sub-ppm concentrations
}

\author{
Masato Hirai, ${ }^{a}$ Mykhaylo Myahkostupov, ${ }^{b}$ Felix N. Castellano, ${ }^{*}, \mathrm{~b}$ and François P. Gabbaï*,a \\ ${ }^{a}$ Department of Chemistry, Texas A\&M University, College Station, Texas 77843-3255, United States. \\ ${ }^{b}$ Department of Chemistry, North Carolina State University, Raleigh, NC 27695-8204, United States
}

\section{SUPPORTING INFORMATION}

Figure S1. ${ }^{1} \mathrm{H}$ NMR spectrum of $1-\mathrm{Br}$ in $\mathrm{CDCl}_{3}$ recorded on a $300 \mathrm{MHz}$ NMR spectrometer at room temperature.

Figure S2. ${ }^{13} \mathrm{C}\left\{{ }^{1} \mathrm{H}\right\}$ NMR spectrum of $1-\mathrm{Br}$ in $\mathrm{CDCl}_{3}$ recorded on a $300 \mathrm{MHz}$ NMR spectrometer at room room temperature.

Figure S3. ${ }^{1} \mathrm{H}$ NMR spectrum of $2-\mathrm{Br}$ in $\mathrm{CDCl}_{3}$ recorded on a $300 \mathrm{MHz}$ NMR spectrometer at room temperature.

Figure S4. ${ }^{13} \mathrm{C}\left\{{ }^{1} \mathrm{H}\right\}$ NMR spectrum of 2-Br in $\mathrm{CDCl}_{3}$ recorded on a $300 \mathrm{MHz}$ NMR spectrometer at room temperature.

Figure S5. ${ }^{1} \mathrm{H}$ NMR spectrum of $2-\mathrm{F}$ in $\mathrm{CDCl}_{3}$ recorded on a $300 \mathrm{MHz} \mathrm{NMR}$ spectrometer at room temperature.

Figure S6. ${ }^{13} \mathrm{C}\left\{{ }^{1} \mathrm{H}\right\}$ NMR spectrum of $2-\mathrm{F}$ in $\mathrm{CDCl}_{3}$ recorded on a $300 \mathrm{MHz}$ NMR spectrometer at room temperature.

Figure S7. ${ }^{19} \mathrm{~F}$ NMR spectrum of $2-\mathrm{F}$ in $\mathrm{CDCl}_{3}$ recorded on a $300 \mathrm{MHz}$ NMR spectrometer at room temperature.

Figure S8. ${ }^{1} \mathrm{H}$ NMR spectrum of $3-\mathrm{Br}$ in $\mathrm{CDCl}_{3}$ recorded on a $300 \mathrm{MHz} \mathrm{NMR}$ spectrometer at room temperature.

Figure S9. ${ }^{13} \mathrm{C}\left\{{ }^{1} \mathrm{H}\right\}$ NMR spectrum of $3-\mathrm{Br}$ in $\mathrm{CDCl}_{3}$ recorded on a $300 \mathrm{MHz}$ NMR spectrometer at room temperature.

Figure S10. ${ }^{1} \mathrm{H}$ NMR spectrum of 3-F in $\mathrm{CDCl}_{3}$ recorded on a $300 \mathrm{MHz}$ NMR spectrometer at room temperature.

Figure S11. ${ }^{13} \mathrm{C}\left\{{ }^{1} \mathrm{H}\right\}$ NMR spectrum of 3-F in $\mathrm{CDCl}_{3}$ recorded on a $300 \mathrm{MHz}$ NMR spectrometer at room temperature.

Figure S12. ${ }^{19} \mathrm{~F}$ NMR spectrum of 3-F in $\mathrm{CDCl}_{3}$ recorded on a $300 \mathrm{MHz}$ NMR spectrometer at room temperature.

Figure S13. Left: change in the fluorescence spectra of 2-Br $\left(7.0 \times 10^{-6} \mathrm{M}\right)$ in $9 / 1(\mathrm{v} / \mathrm{v}) \mathrm{H}_{2} \mathrm{O} / \mathrm{DMSO}$ containing CTAB $(10 \mathrm{mM})$ at $\mathrm{pH} 4.8$ (pyridine buffer) upon incremental addition of fluoride. Right: plot of fluorescence intensity increase at $\lambda_{\text {fluo }}=379 \mathrm{~nm}$ of $2-\mathrm{Br}$ after successive addition of fluoride anions.

Figure S14. Left: spectral changes in the emission spectrum of 3-Br upon incremental addition of fluoride anions; Right: plot of fluorescence intensity increase at $\lambda_{\text {fluo }}=461 \mathrm{~nm}$ of 3-Br after successive addition of fluoride anions. 


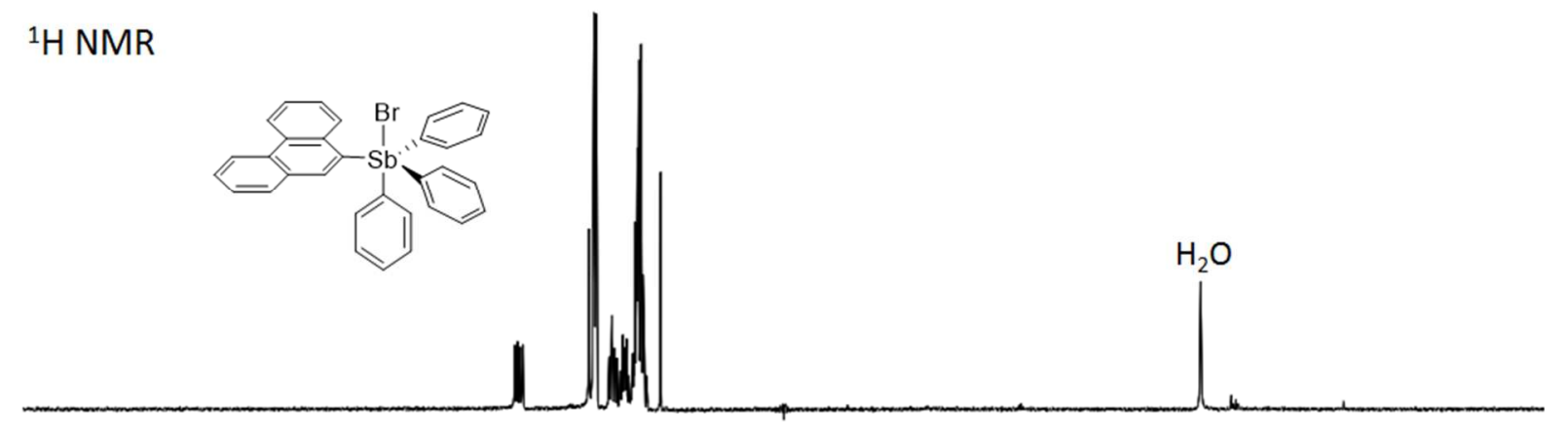

\begin{tabular}{|c|c|c|c|c|c|c|c|c|c|c|c|c|c|c|}
\hline 13 & 12 & 11 & 10 & 9 & 8 & 7 & 6 & 5 & 4 & 3 & 2 & 1 & 0 & ppm \\
\hline
\end{tabular}
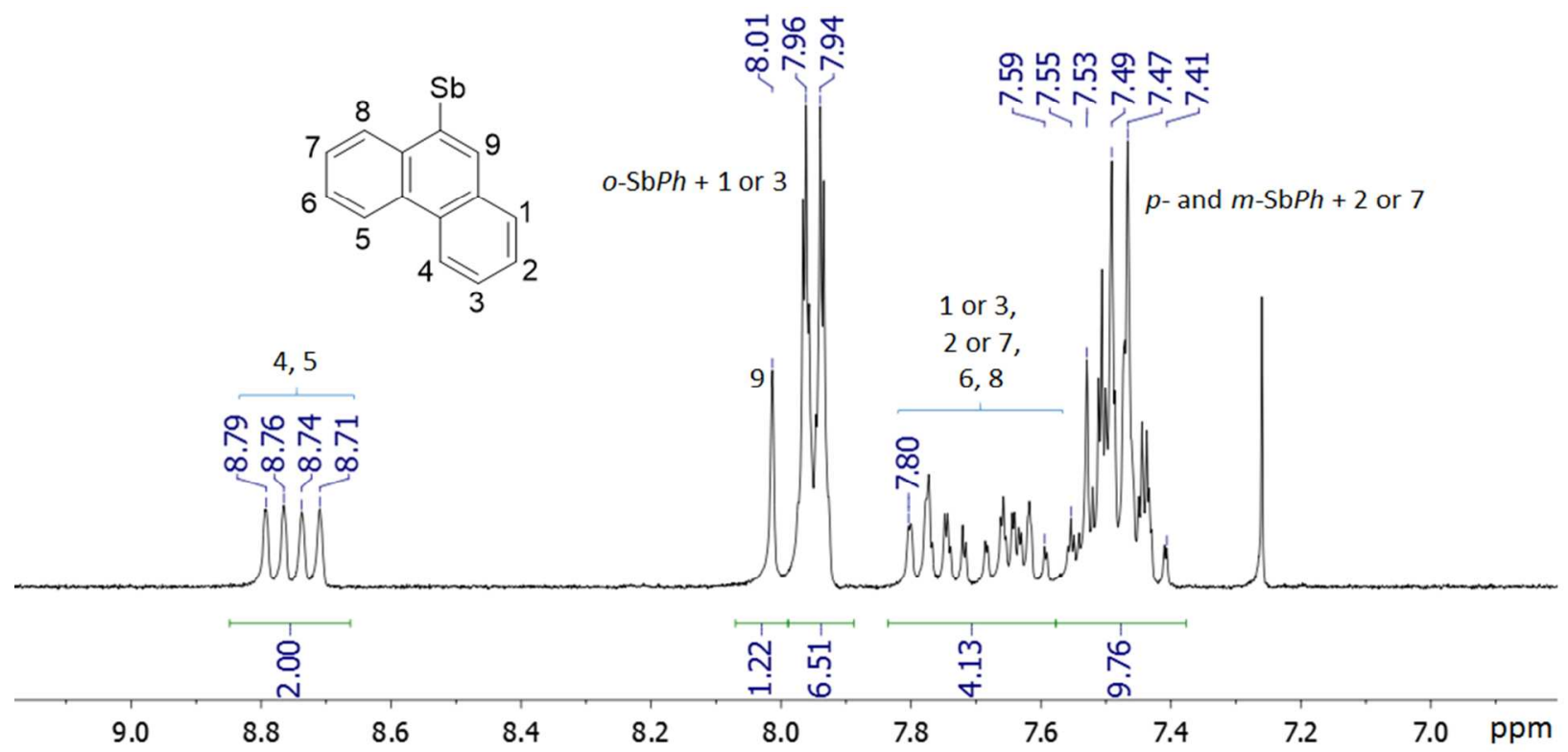

Figure S1. ${ }^{1} \mathrm{H}$ NMR spectrum of $1-\mathrm{Br}$ in $\mathrm{CDCl}_{3}$ recorded on a $300 \mathrm{MHz}$ NMR spectrometer at room temperature. 


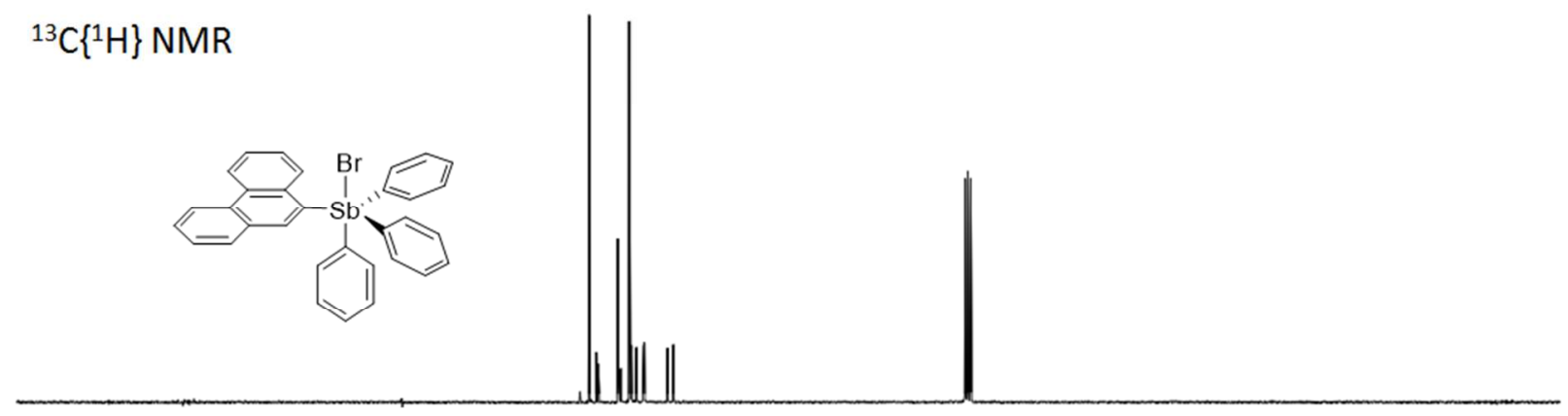

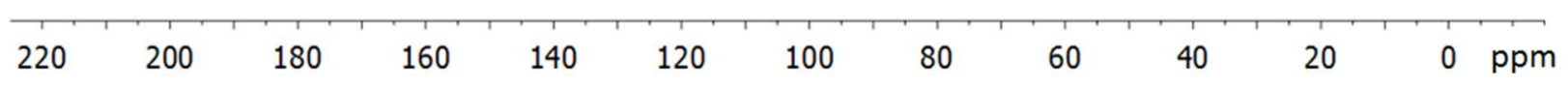

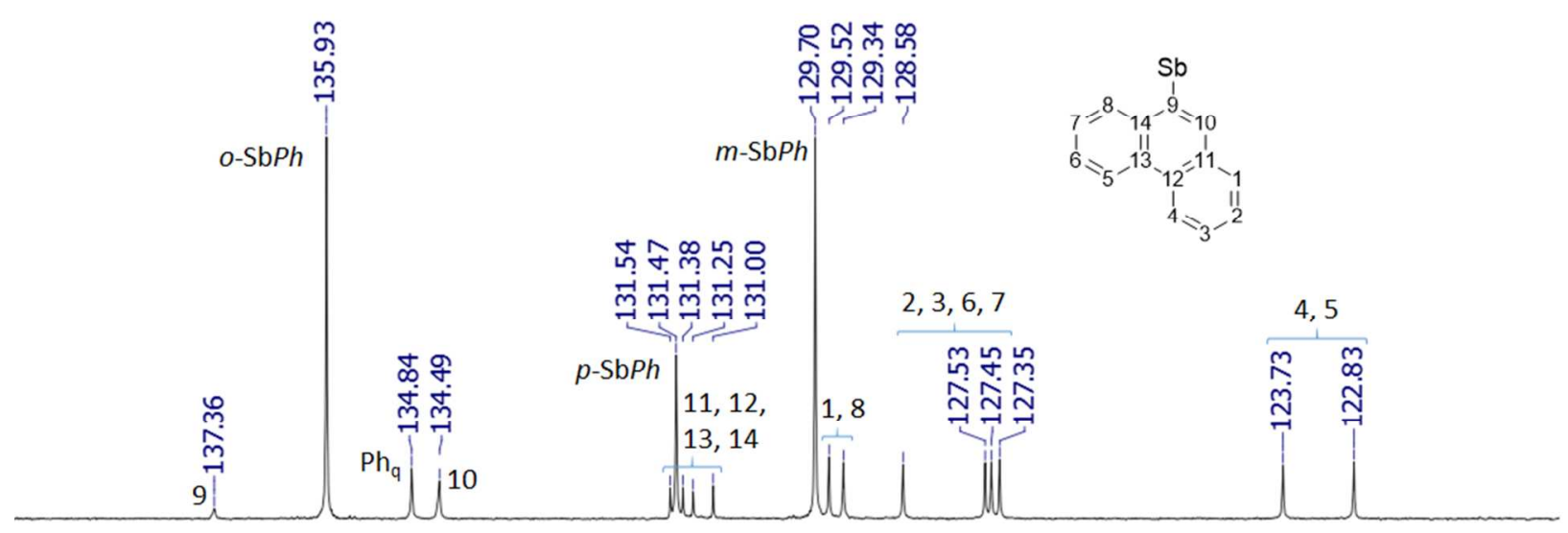

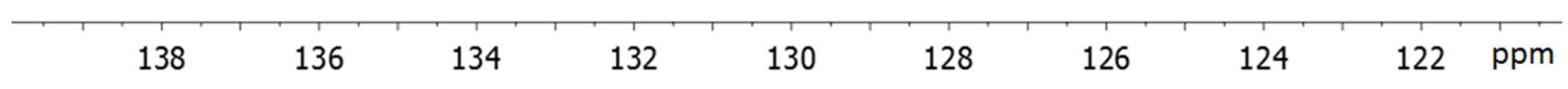

Figure S2. ${ }^{13} \mathrm{C}\left\{{ }^{1} \mathrm{H}\right\}$ NMR spectrum of $\mathbf{1}-\mathrm{Br}$ in $\mathrm{CDCl}_{3}$ recorded on a $300 \mathrm{MHz}$ NMR spectrometer at room room temperature. 


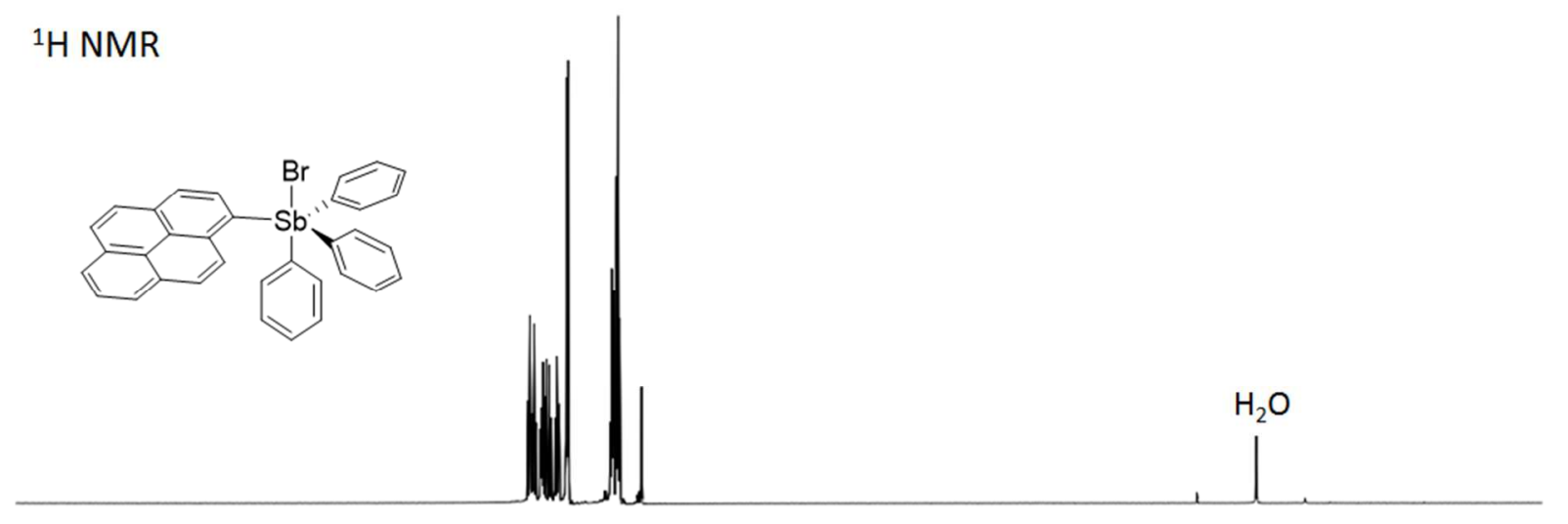

\begin{tabular}{llllllllllllllll}
\hline 12 & 11 & 10 & 9 & 8 & 7 & 6 & 5 & 4 & 3 & 2 & 1 & 0 & $\mathrm{ppm}$
\end{tabular}

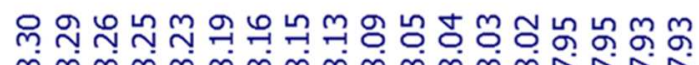
$\infty \infty \infty \infty \infty \infty \infty \infty \infty \infty \infty \infty \infty \infty \infty) \infty N$

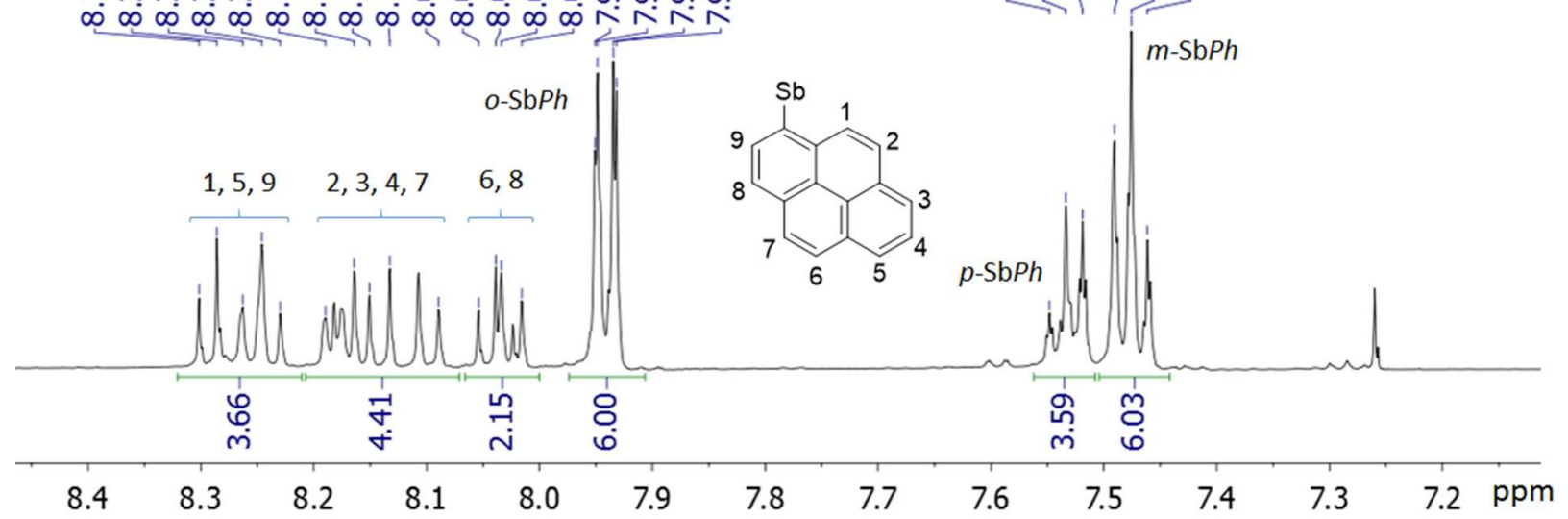

Figure S3. ${ }^{1} \mathrm{H}$ NMR spectrum of $2-\mathrm{Br}$ in $\mathrm{CDCl}_{3}$ recorded on a $300 \mathrm{MHz}$ NMR spectrometer at room temperature. 


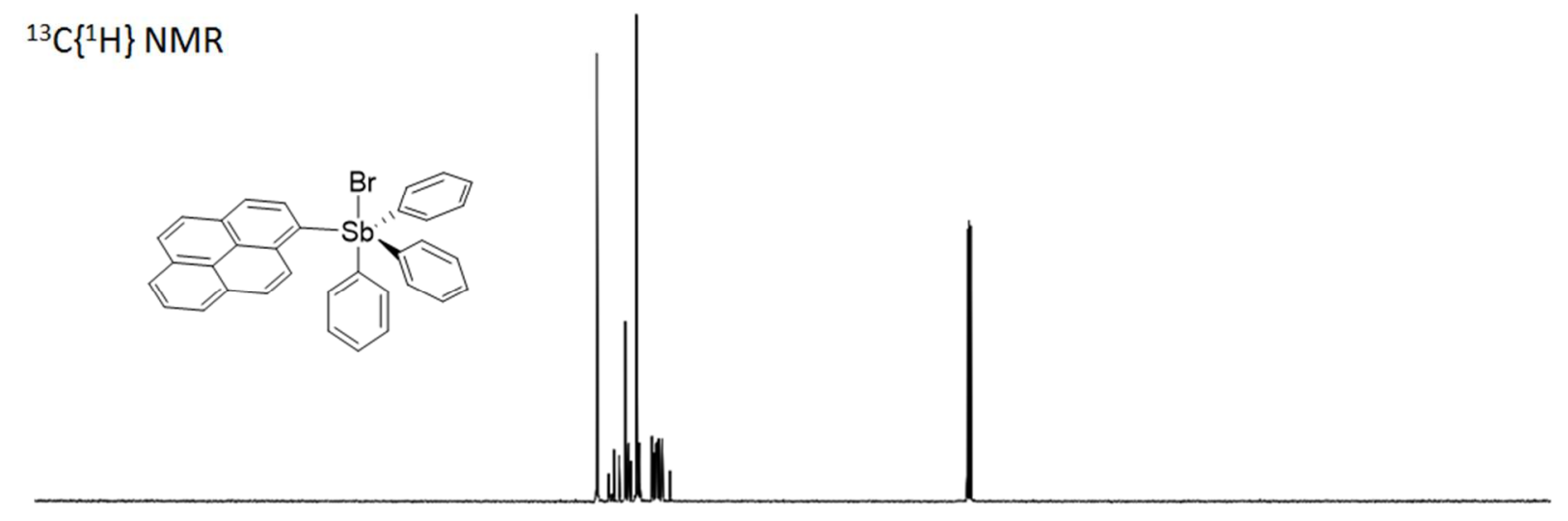

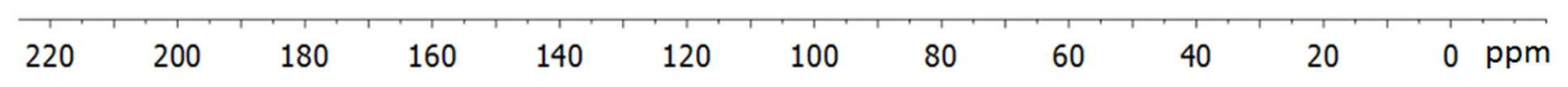

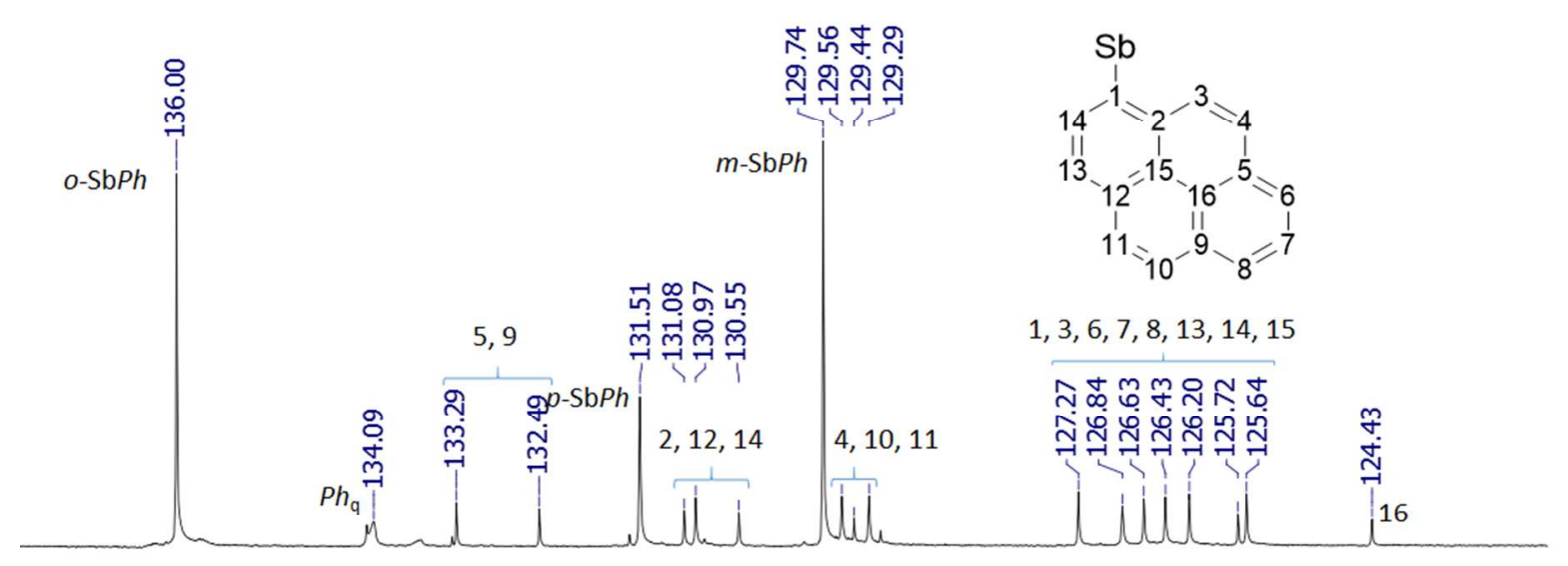

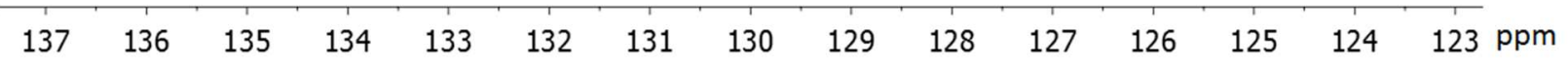

Figure S4. ${ }^{13} \mathrm{C}\left\{{ }^{1} \mathrm{H}\right\}$ NMR spectrum of 2- $\mathrm{Br}$ in $\mathrm{CDCl}_{3}$ recorded on a $300 \mathrm{MHz}$ NMR spectrometer at room temperature. 


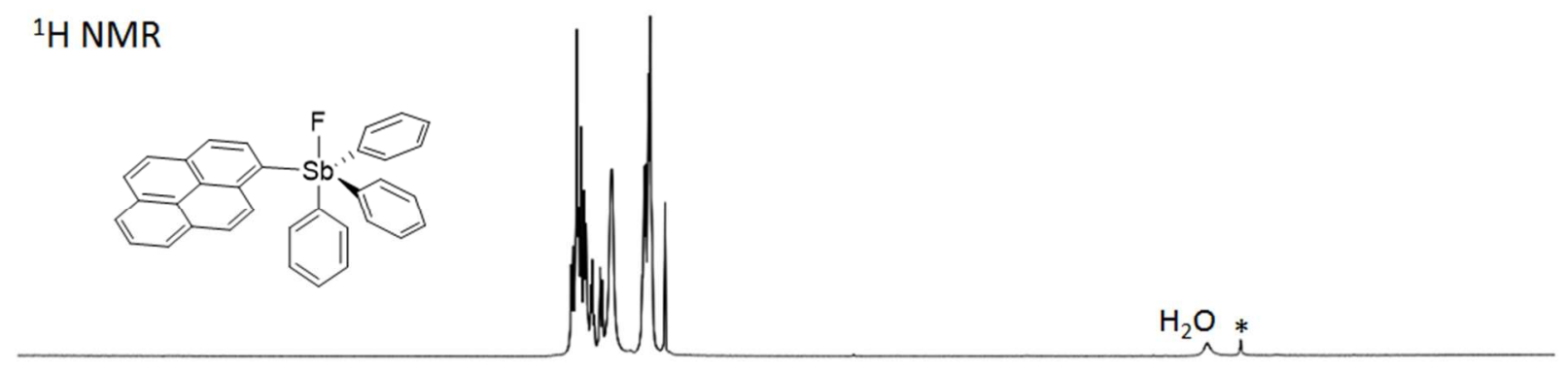

$\begin{array}{llllllllllllllll} & 13 & 12 & 11 & 10 & 9 & 8 & 7 & 6 & 5 & 4 & 3 & 2 & 1 & 0 & -1\end{array}$

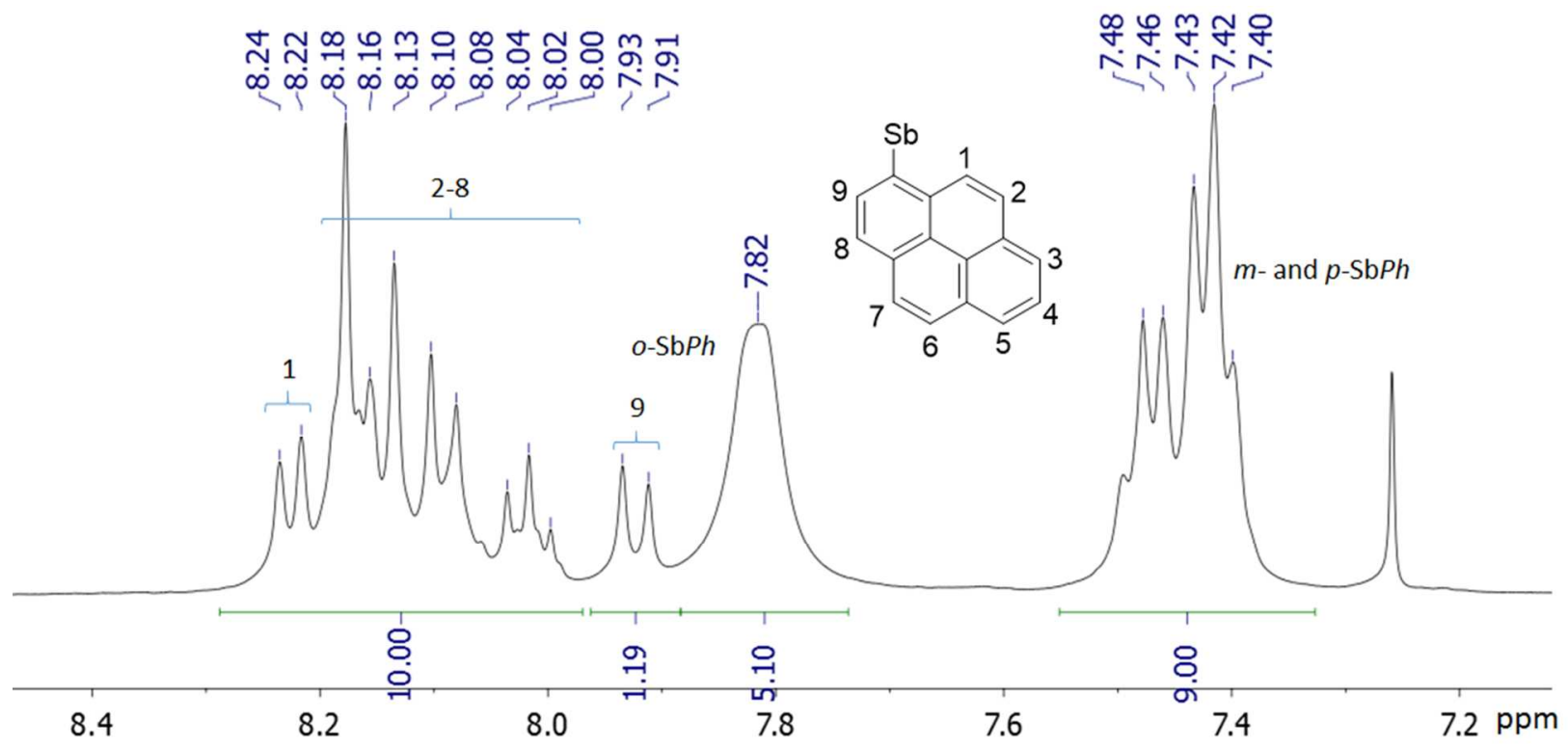

Figure S5. ${ }^{1} \mathrm{H}$ NMR spectrum of 2-F in $\mathrm{CDCl}_{3}$ recorded on a $300 \mathrm{MHz} \mathrm{NMR}$ spectrometer at room temperature. Signal marked as “*” is an unknown impurity from the solvent. 


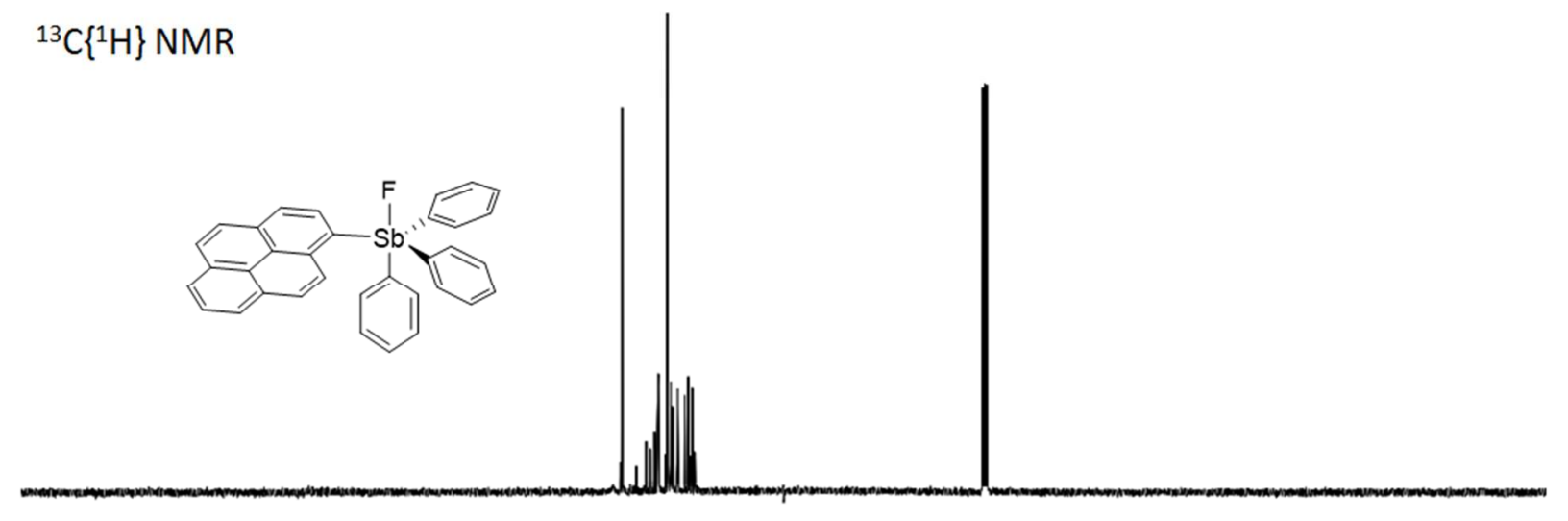

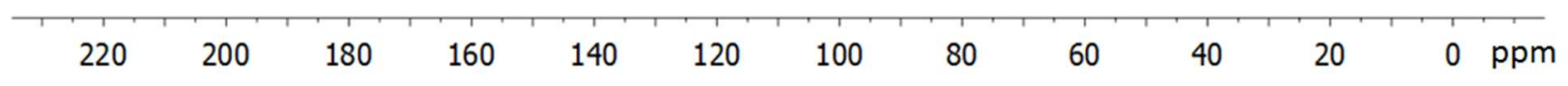

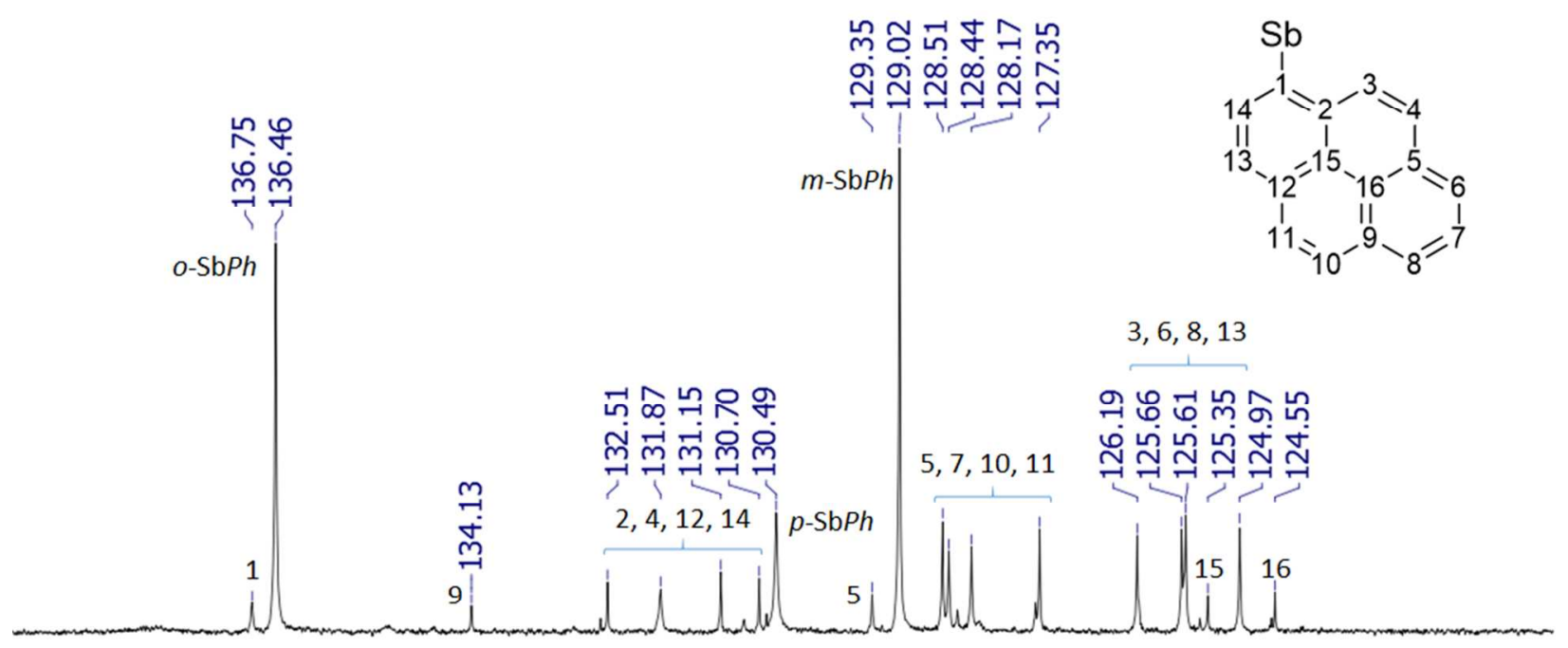

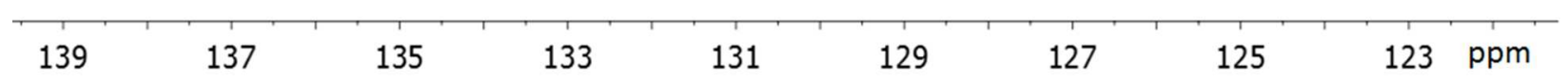

Figure S6. ${ }^{13} \mathrm{C}\left\{{ }^{1} \mathrm{H}\right\}$ NMR spectrum of $2-\mathrm{F}$ in $\mathrm{CDCl}_{3}$ recorded on a $300 \mathrm{MHz}$ NMR spectrometer at room temperature.

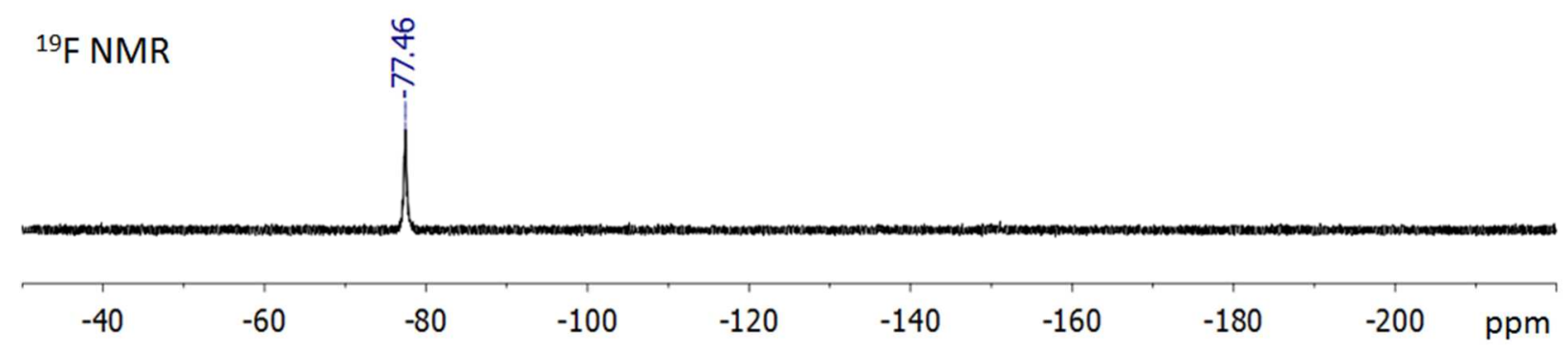

Figure S7. ${ }^{19} \mathrm{~F}$ NMR spectrum of $2-\mathrm{F}$ in $\mathrm{CDCl}_{3}$ recorded on a $300 \mathrm{MHz}$ NMR spectrometer at room temperature. 


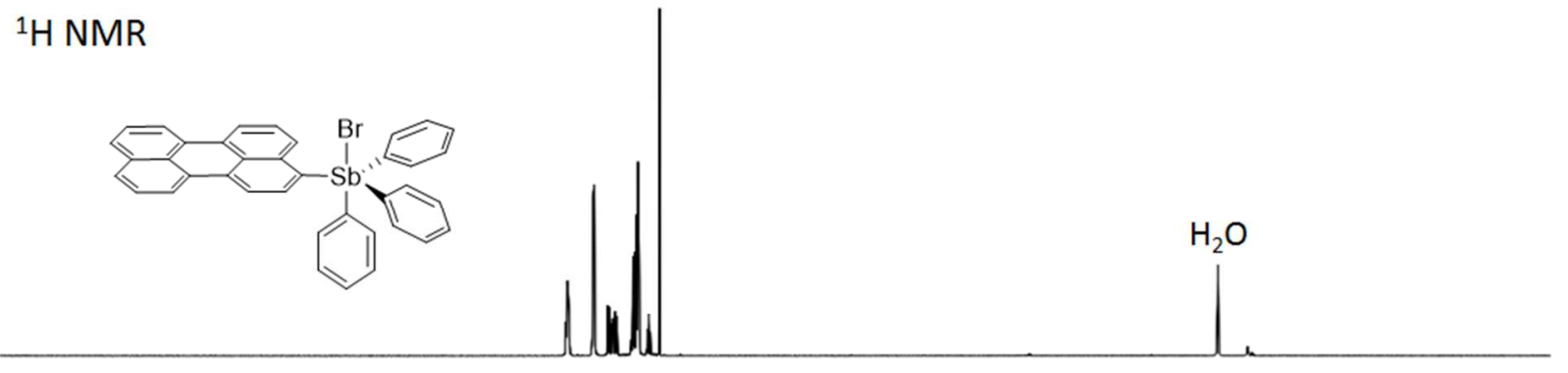

\begin{tabular}{lllllllllllllll}
\hline 13 & 12 & 11 & 10 & 9 & 8 & 7 & 6 & 5 & 4 & 3 & 2 & 1 & 0 & -1 \\
$\mathrm{ppm}$
\end{tabular}

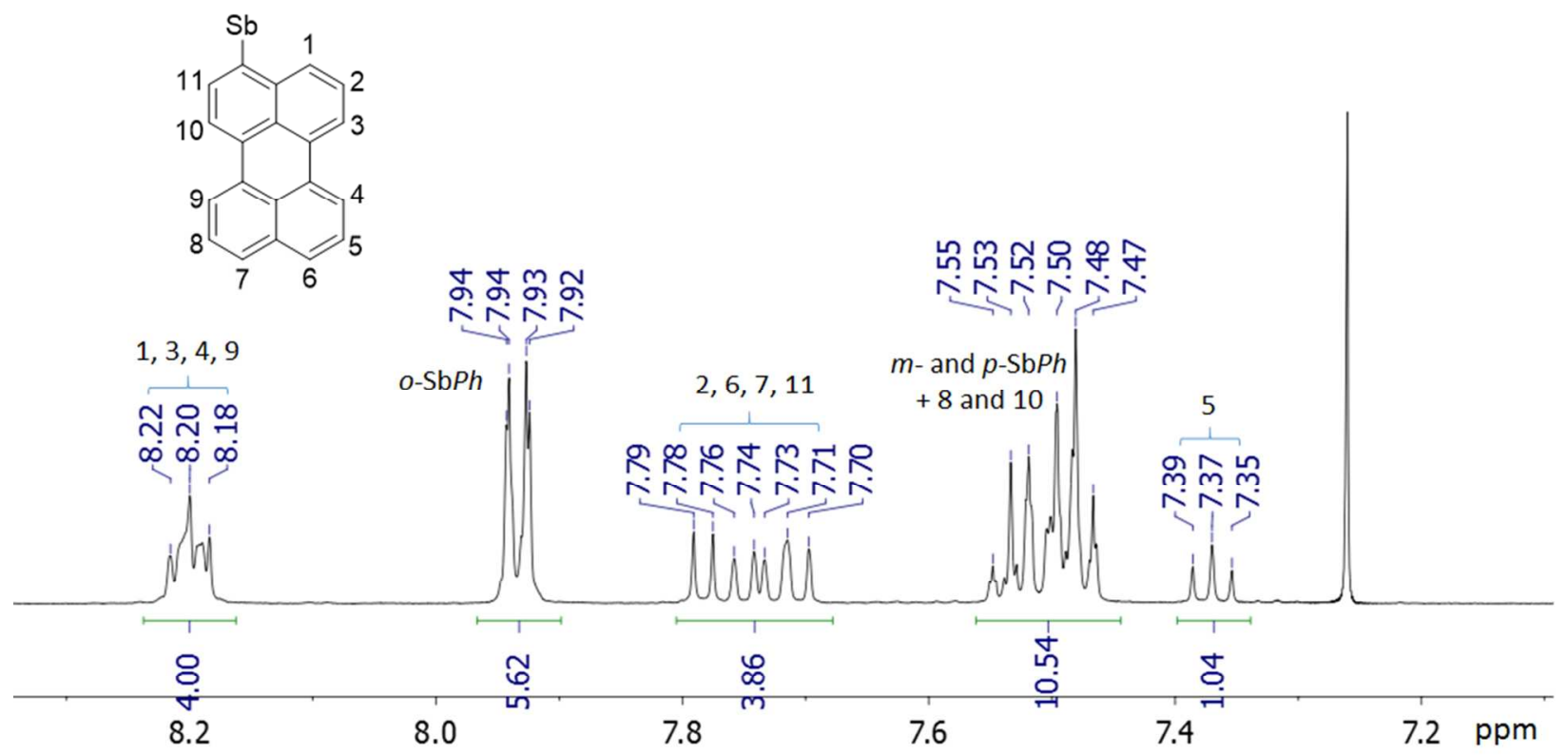

Figure S8. ${ }^{1} \mathrm{H}$ NMR spectrum of $3-\mathrm{Br}$ in $\mathrm{CDCl}_{3}$ recorded on a $300 \mathrm{MHz} \mathrm{NMR}$ spectrometer at room temperature. 


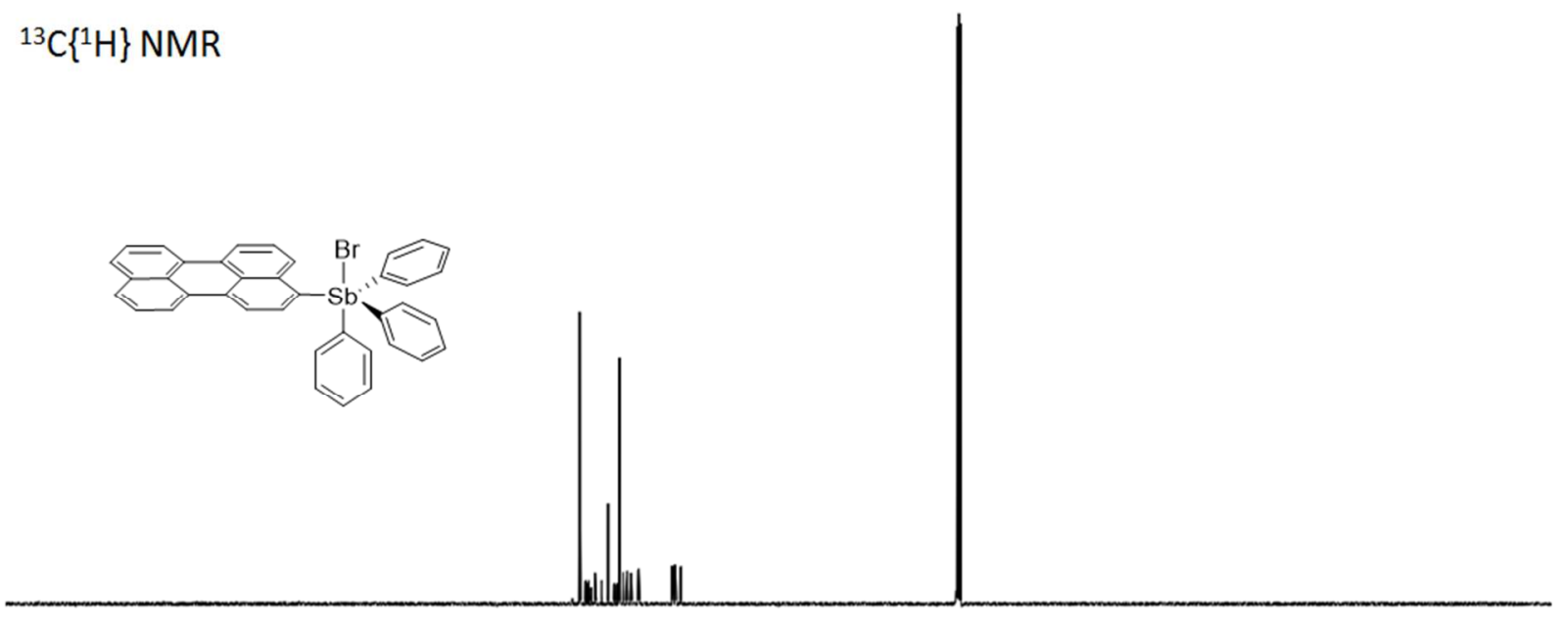

\begin{tabular}{lllllllllllll}
\hline 220 & 200 & 180 & 160 & 140 & 120 & 100 & 80 & 60 & 40 & 20 & 0 & $\mathrm{ppm}$
\end{tabular}

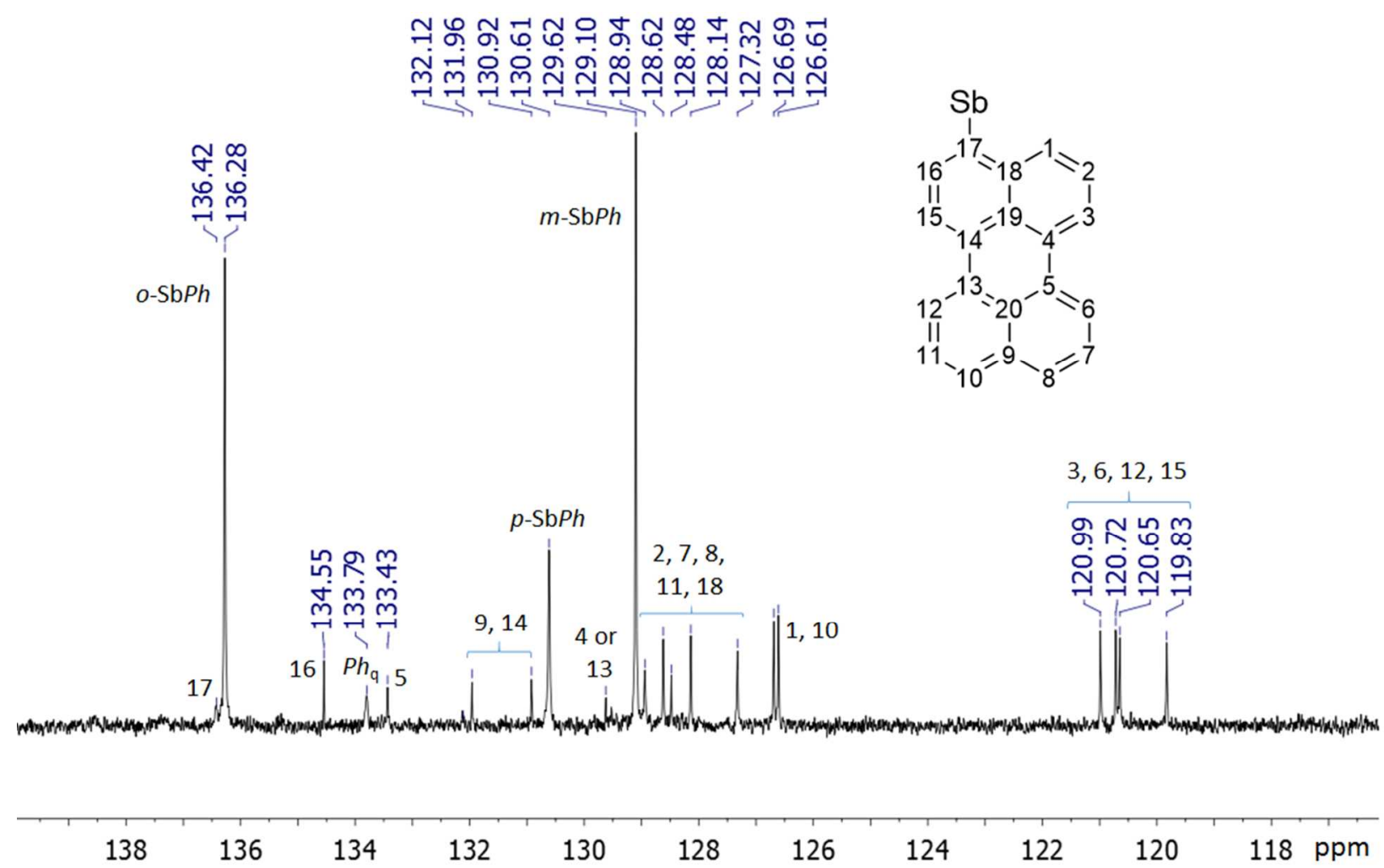

Figure S9. ${ }^{13} \mathrm{C}\left\{{ }^{1} \mathrm{H}\right\}$ NMR spectrum of 3-Br in $\mathrm{CDCl}_{3}$ recorded on a $300 \mathrm{MHz}$ NMR spectrometer at room temperature. 


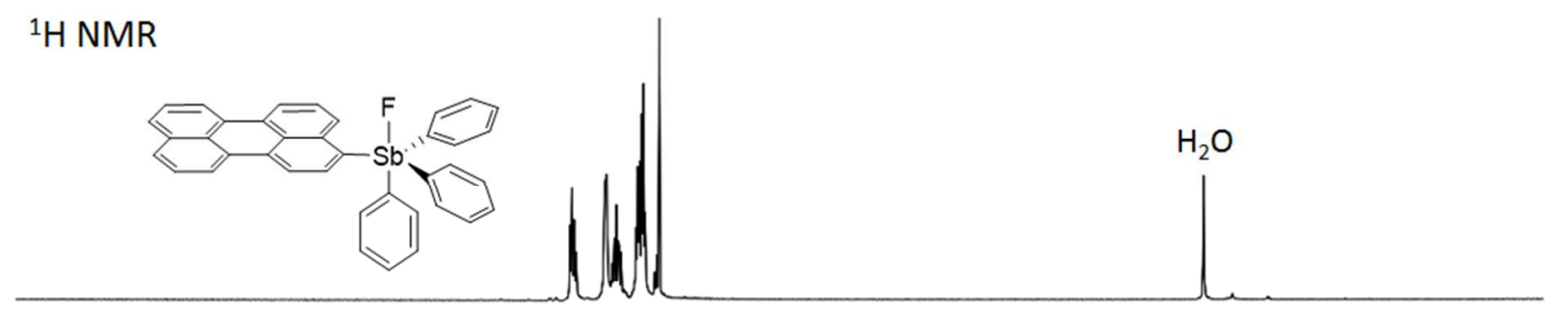

\begin{tabular}{lllllllllllllllll}
\hline 13 & 12 & 11 & 10 & 9 & 8 & 7 & 6 & 5 & 4 & 3 & 2 & 1 & 0 & -1 & $\mathrm{ppm}$
\end{tabular}

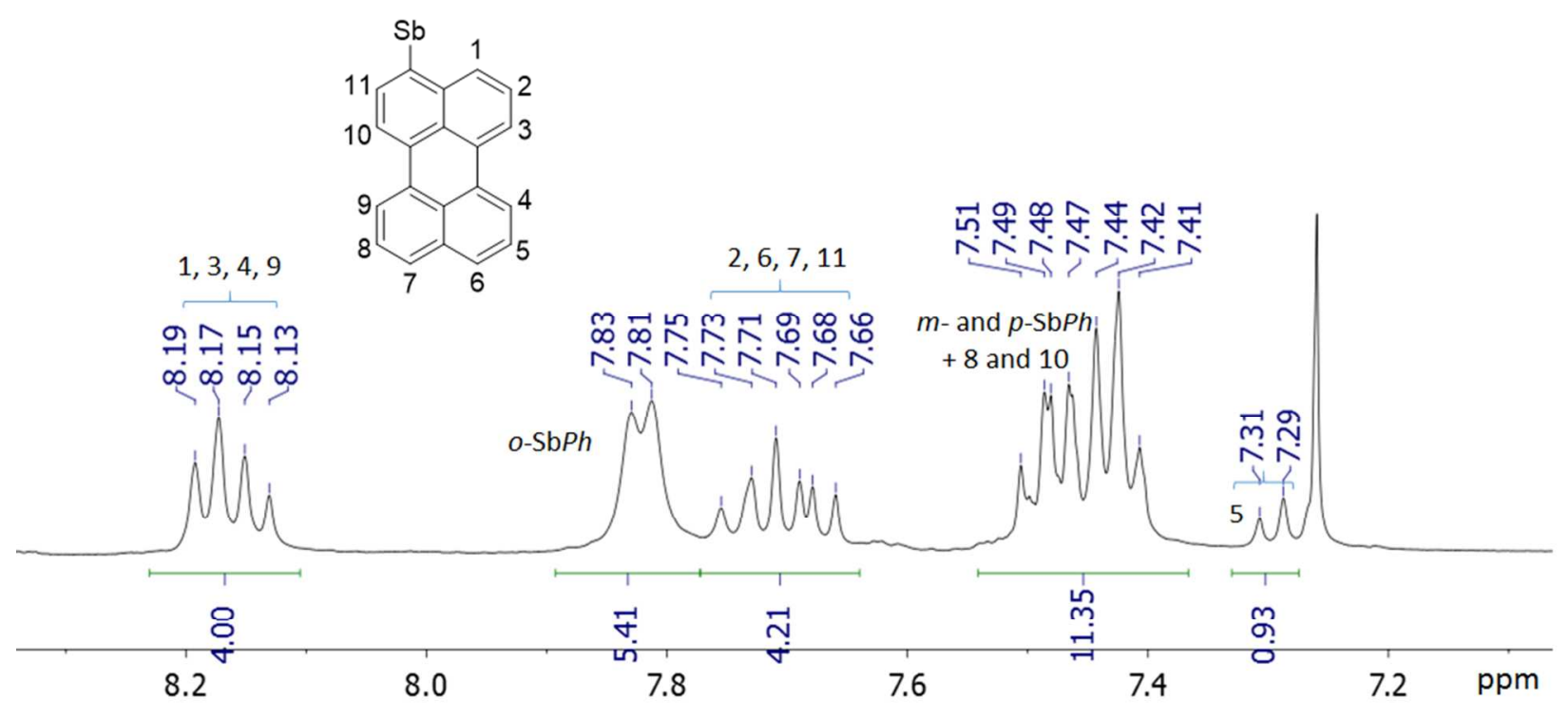

Figure S10. ${ }^{1} \mathrm{H}$ NMR spectrum of 3-F in $\mathrm{CDCl}_{3}$ recorded on a $300 \mathrm{MHz}$ NMR spectrometer at room temperature. 


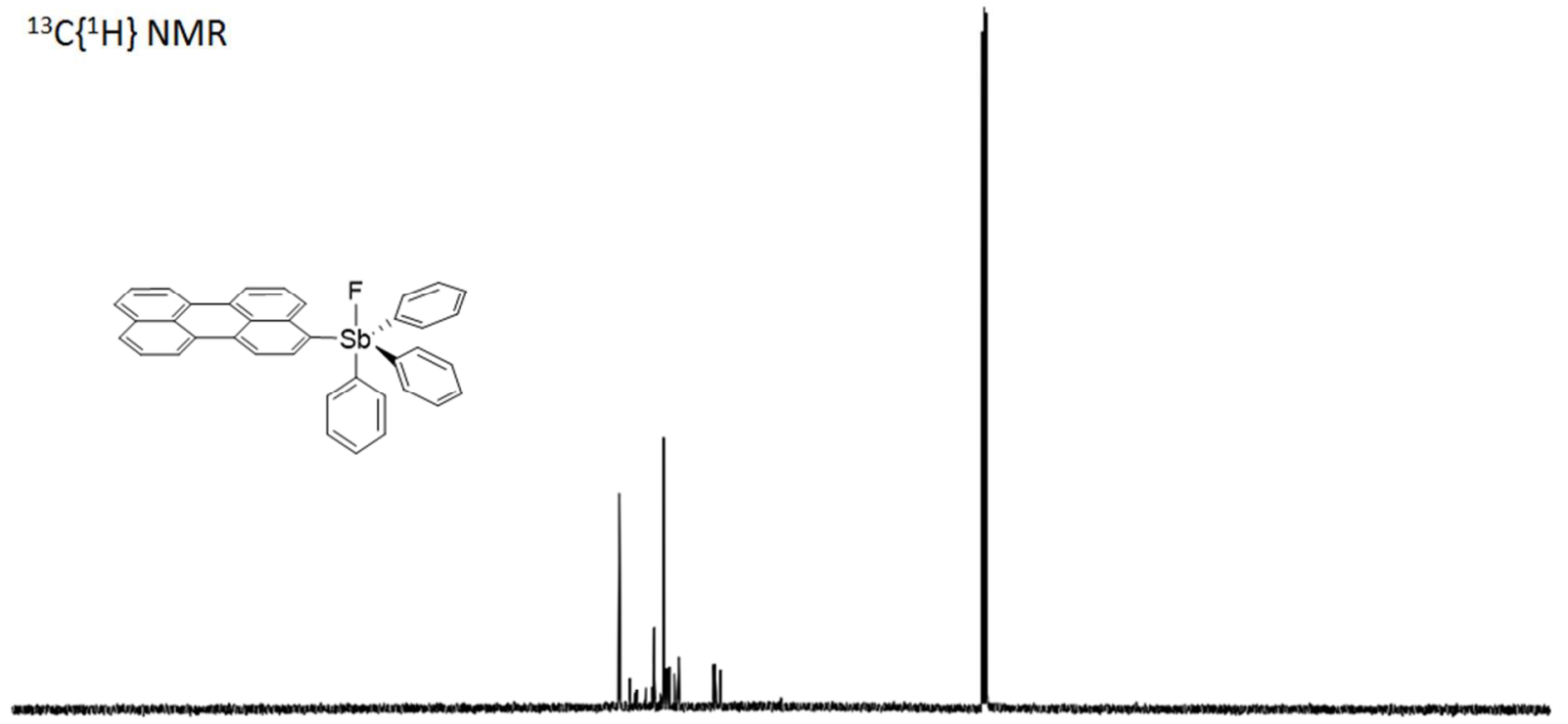

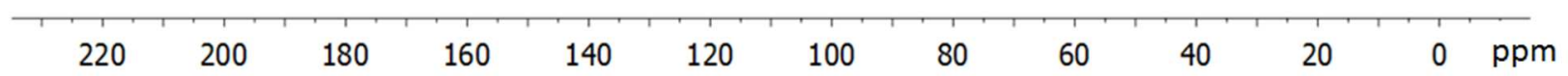

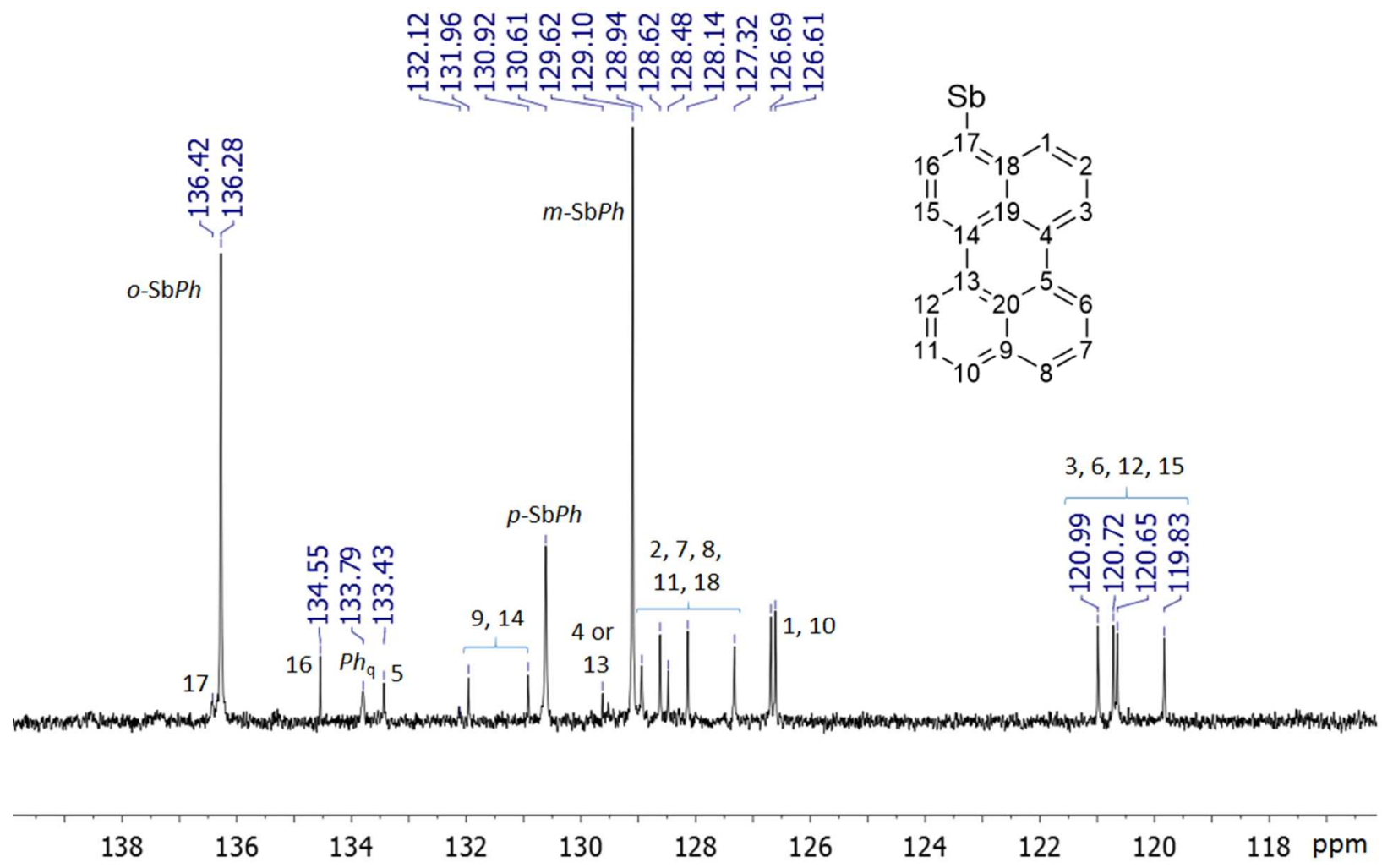

Figure S11. ${ }^{13} \mathrm{C}\left\{{ }^{1} \mathrm{H}\right\}$ NMR spectrum of 3-F in $\mathrm{CDCl}_{3}$ recorded on a $300 \mathrm{MHz}$ NMR spectrometer at room temperature. 


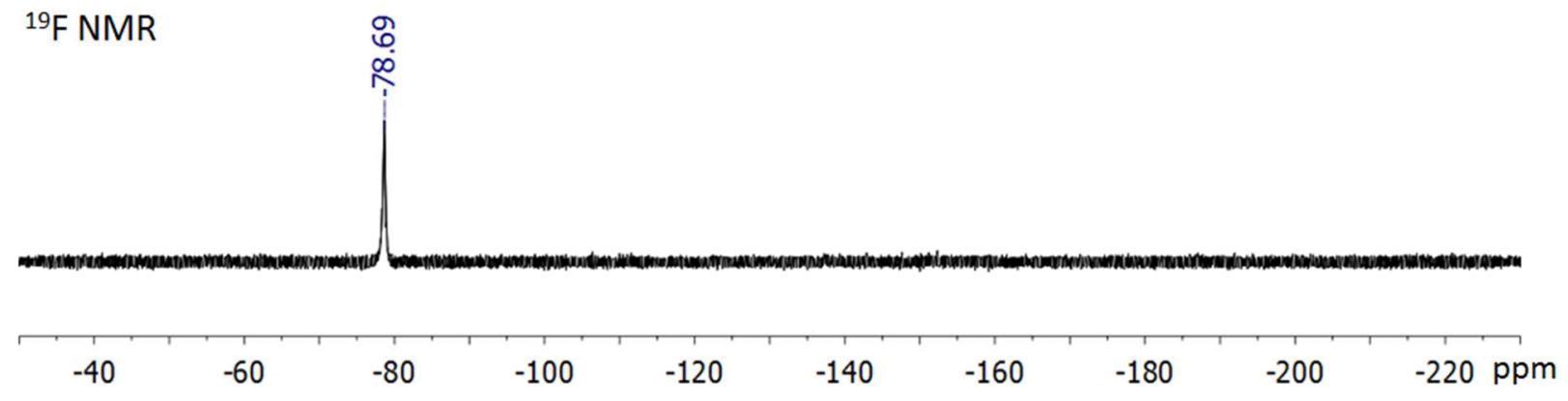

Figure S12. ${ }^{19} \mathrm{~F}$ NMR spectrum of 3-F in $\mathrm{CDCl}_{3}$ recorded on a $300 \mathrm{MHz}$ NMR spectrometer at room temperature. 

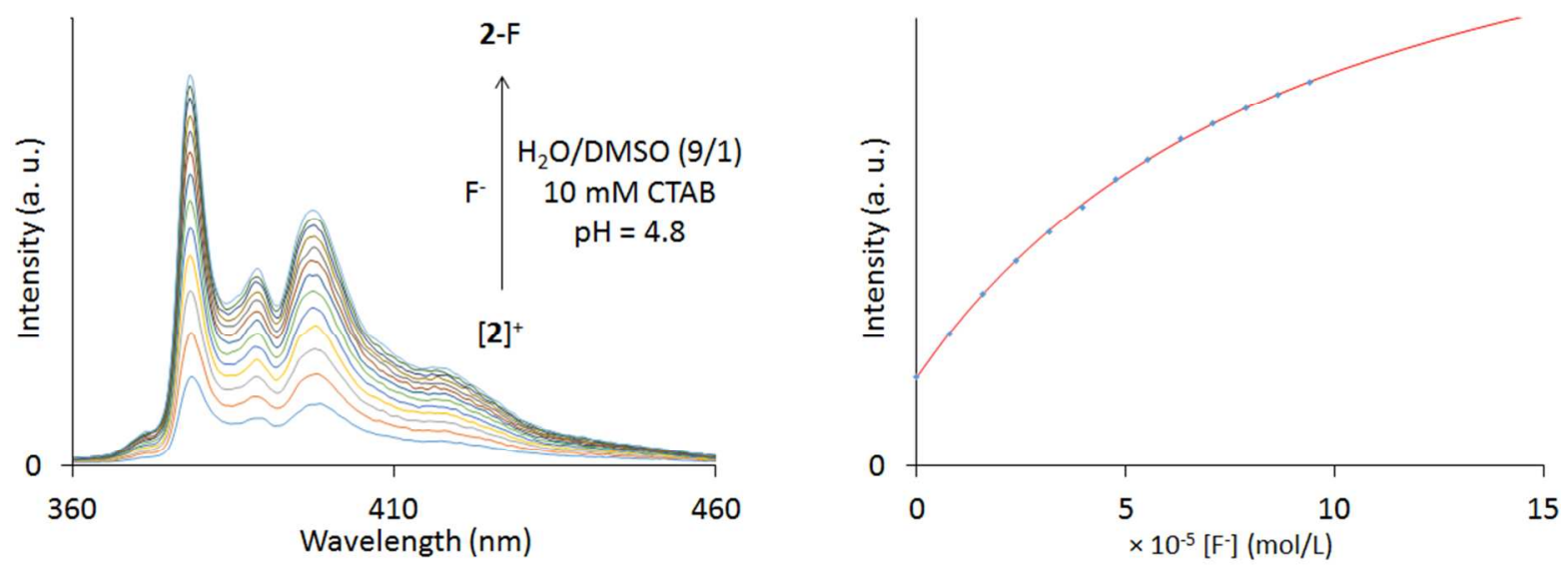

Figure S13. Left: change in fluorescence spectra of 2- $\mathrm{Br}\left(7.0 \times 10^{-6} \mathrm{M}\right)$ in $9 / 1(\mathrm{v} / \mathrm{v}) \mathrm{H}_{2} \mathrm{O} / \mathrm{DMSO}$ containing CTAB $(10 \mathrm{mM})$ at $\mathrm{pH} 4.8$ (pyridine buffer) upon incremental addition of fluoride. Right: plot of fluorescence intensity increase at $\lambda_{\text {fluo }}=379 \mathrm{~nm}$ of $2-\mathrm{Br}$ after successive addition of fluoride anions.

\section{Tap water fluoride concentration test.}

1. Standard curve:

The method we applied was adopted from a reported procedure. A DMSO solution of 3-Br $(0.3 \mathrm{~mL}, 5 \times$ $10^{-5} \mathrm{M}$ ) was combined with i) an aqueous CTAB (cetyltrimethylammonium bromide, $10 \mathrm{mM}$ ) solution $\left(1.7 \mathrm{~mL}\right.$ ) buffered at $\mathrm{pH} 4.8$ (pyridine buffer, $10 \mathrm{mM}$ ) and ii) $\mathrm{H}_{2} \mathrm{O}(1 \mathrm{~mL})$. The resulting mixture was titrated by addition of a KF solution in water $(0.0075 \mathrm{M})$. The experiment was monitored by fluorescence spectroscopy. The fluorescence intensity at $461 \mathrm{~nm}$ was used to generate a standard curve.
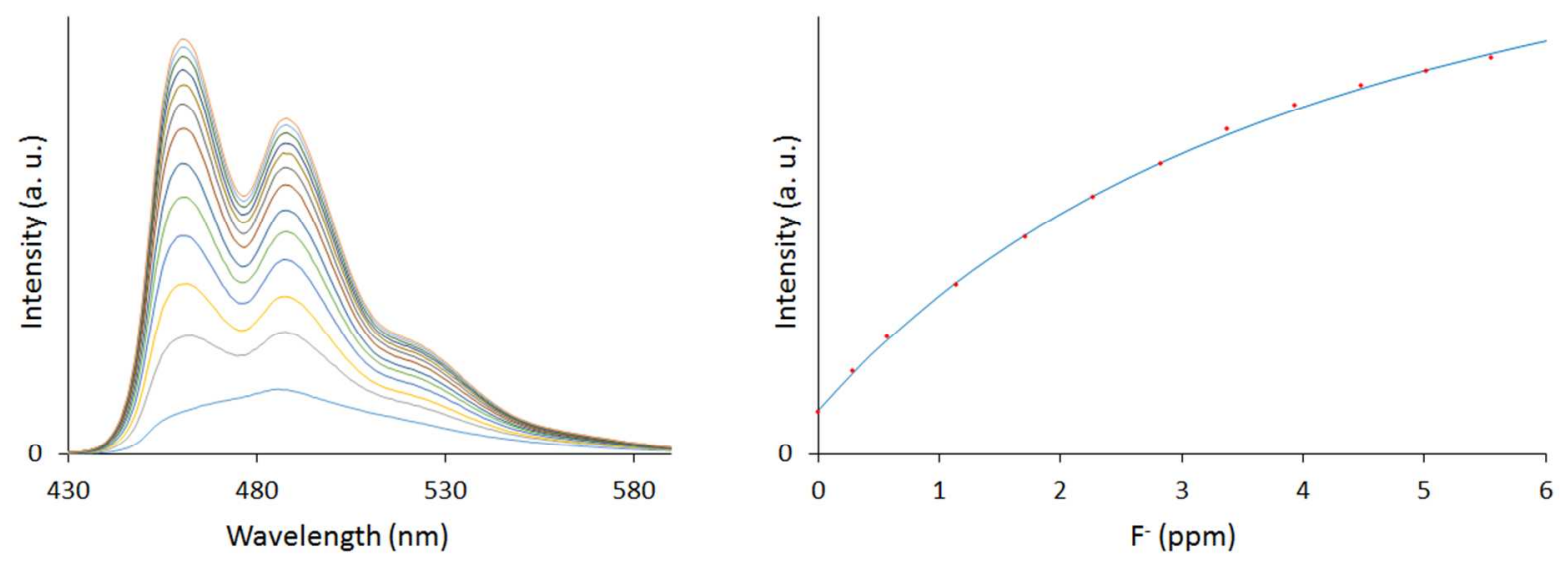

Figure S14. Left: spectral changes in the emission spectrum of 3-Br upon incremental addition of fluoride anions; Right: plot of fluorescence intensity increase at $\lambda_{\text {fluo }}=461 \mathrm{~nm}$ of 3-Br after successive addition of fluoride anions. 


\section{Sample water test}

The method we applied was adopted from a reported procedure. A DMSO solution of 3-Br $(0.3 \mathrm{~mL}, 5 \times$ $10^{-5} \mathrm{M}$ ) was combined with i) an aqueous CTAB (cetyltrimethylammonium bromide, $10 \mathrm{mM}$ ) solution $(1.7 \mathrm{~mL})$ buffered at $\mathrm{pH} 4.8$ (pyridine buffer, $10 \mathrm{mM})$ and ii) water sample to analyze $(1 \mathrm{~mL})$. The resulting mixture was stirred for 5 min before an emission spectrum was recorded $\left(\lambda_{\text {excitation }}=423 \mathrm{~nm}\right)$. The data from the fluorescence measurements are listed below in Table S1 (intensities measured at $\lambda_{\text {fluo }}=$ $461 \mathrm{~nm}$ ). The water samples were also analyzed by ion chromatography to further verify the fluoride concentrations. The reported fluoride concentration values were obtained from the City of College Station website (http://www.cstx.gov/index.aspx?page=822) for College Station tap water (last update in 2014) and Nestle Waters ${ }^{\circledR}$ North America website (http://www.nestle-watersna.com/en/bottled-watersources-and-quality/water-quality-reports) for Ozarka ${ }^{\circledR}$ (added fluoride) sample (last update in 2013). No newer water quality reports are available from these sources.

Table S1. Results of the fluoride anion sensing assay using $[3]^{+}$as a sensor.

\begin{tabular}{ccccc} 
Sample & Em $_{461}$ & $\mathrm{~F}^{-}$ppm $\left(\right.$by $\left.[3]^{+}\right)$ & $\mathrm{F}^{-}$ppm (by IC) & F $^{-}$ppm (reported) \\
\hline Tap water & 189912 & $0.48( \pm 0.03)$ & 0.45 & 0.48 \\
$\begin{array}{c}\text { Ozarka }{ }^{\circledR} \\
\text { (added fluoride) }\end{array}$ & 243366 & $0.74( \pm 0.06)$ & 0.73 & 0.72 \\
\hline
\end{tabular}

